\title{
Life without Toothache: Hans Blumenberg's Zettelkasten and History of Science as Theoretical Attitude
}

\author{
Daniela K. Helbig
}

There is a box stored in the German Literature Archive in Marbach, the wooden box Hans Blumenberg kept in a fireproof steel cabinet, for it contained his collection of about thirty thousand typed and handwritten note cards. ${ }^{1}$ Note cards that Blumenberg used as mnemonics for the crafted improvisation characteristic of his talks and lectures, for writing his manuscripts, and also for dictating his books from The Legitimacy of the Modern Age onward to stenorette tapes then delivered from the ever more determined recluse to his secretary for her to type up their contents. ${ }^{2}$ Note cards he struck through once or several times in red ink once he'd used them, then wrapped and hid away to avoid the risk of using them too often-a system so integral to his own method of thinking and writing that it shaped his understanding of other writers' processes; for instance, he accused Montaigne of having "used up" a quote from Lucretius by employing it to illustrate a minor paradox, rather than saving it, as Blumenberg deemed "compulsory," for his major argument regarding the failure of states. ${ }^{3}$ Note

\footnotetext{
${ }^{1}$ See Ulrich von Bülow and Dorit Krusche, "Vorläufiges zum Nachlass von Hans Blumenberg," in Hans Blumenberg beobachtet: Wissenschaft, Technik und Philosophie, ed. Cornelius Borck (Freiburg and Munich: Alber, 2013), 273-88.

2 Odo Marquard, "Entlastung vom Absoluten," in Die Kunst des Überlebens: Nachdenken über Hans Blumenberg, ed. Franz Josef Wetz and Herrmann Timm (Frankfurt: Suhrkamp, 1999), 17-27, 18.

3 "Verbraucht"; "müßte . . zwingend naheliegen," Hans Blumenberg, Schiffbruch mit
} 
cards that provided the associative thread for weighty books, for slim collections of essays, for mere paragraphs, until finally this massive material system of text production ceased to put out publications, leaving volumes of work that are still being released by other scholars since Blumenberg's death. "For whom?" he allegedly asked. ${ }^{4}$

The elaborate system of his Zettelkasten, or note-card box, is useful in situating Hans Blumenberg as a historian and philosopher of science and technology. In the Anglophone field of Science Studies, even if this field is construed broadly as comprising historical, philosophical, sociological, and anthropological approaches, he is not read widely. ${ }^{5}$ This lack of attention may be partially attributable to his difficult style. Joseph Leo Koerner, who sees Blumenberg's work as "one of the most important intellectual achievements of our time," argues that his "resolutely circular beginnings, written in an aphoristic style that refuses to establish the argument's starting point or itinerary, are Blumenberg's most difficult and characteristic achievements." 6 Blumenberg's style and exceptionally wide-ranging oeuvre resist summary or distillation. Against attempts to sloganize his work-in particular Odo Marquard's suggestion that Blumenberg's philosophy is summed up by the basic idea of the "relief from the absolute"-his former student Ahlrich Meyer advocates for the "charm of discoveries" in an "incomplete and purposefully unsystematic" body of work.7 The editors of the recent collection Blumenberg lesen (Reading Blumenberg) go further still, starting from the premise that Blumenberg's writings challenge the very notion of reading. Not only is the content of Blumenberg's texts demanding, given their scope and erudition and their refusal to offer conclusive answers or synthesis, but so is their frequent argumentative reliance on that which remains unsaid. The legibility of

Zuschauer: Paradigma einer Daseinsmetapher (Frankfurt: Suhrkamp, 1979), 19. Translated into English by Steven Rendall as Shipwreck With Spectator: Paradigm for a Metaphor of Existence (Cambridge, MA: MIT Press, 1997), 16. Translations are the author's, with the exception of quotations from published translations of Blumenberg's works.

4 "Für wen eigentlich?" Marquard, "Entlastung," 27.

${ }^{5}$ On Blumenberg as a historian of science and technology within German and Anglophone approaches to the history and philosophy of science, see Borck, Blumenberg beobachtet.

${ }^{6}$ Joseph L. Koerner, "Ideas about the Thing, not the Thing Itself: Hans Blumenberg's Style," History of the Human Sciences 6, no. 4 (1993): 1-10, esp. 2-3.

7 "Zugleich hat . . . das Gesamtwerk etwas Unabgeschlossenes und absichtsvoll Unsystematisches. Daher bringt sich um den Reiz von Entdeckungen, wer [dar]aus . . . einen Grundgedanken zu destillieren sucht," Ahlrich Meyer, "Hans Blumenberg oder: Die Kunst, sich herauszuhalten," in Fliegende Fische: Eine Soziologie des Intellektuellen in 20 Porträts, ed. Thomas Jung and Stefan Müller-Doohm (Frankfurt: Fischer, 2009), 337-62, at 338 . 
his own books is one question that the author of the Legibility of the World left implicit. ${ }^{8}$

Regarding his work on the sciences, Blumenberg did not facilitate his reception within the Anglophone tradition by engaging much with it. He may have initiated the translation of The Structure of Scientific Revolutions into German, but, with the exception of some brief mentions, he limited his discussion of Kuhn to a short article crediting Georg Christoph Lichtenberg with a much more sophisticated concept of "paradigm." This lack of dialogue with one of the most prominent exponents of Anglophone Science Studies and that field's thematic and methodological interests is characteristic of Blumenberg's work. To the extent that Blumenberg's texts on the sciences engage the work of his contemporaries, they are mostly members of the intellectual circles of the German Federal Republic such as Adorno and Horkheimer, Gadamer, and Heidegger. ${ }^{10}$ From his idiosyncratic position between the political left and right, Blumenberg articulated a perspective on the sciences in opposition to the element that unites its influential critiques on either end of that spectrum. Adorno and Horkheimer's critique of instrumental reason in Dialectic of Enlightenment, Gadamer's geisteswissenschaftliche hermeneutics, and Heidegger's stylization of science and technology as a metaphysical threat all accept the premise of a possible distinction between the humanities and the sciences in terms of their respective explanatory aims, broadly in continuation of the ancient distinction between knowledge of the self and knowledge of the world.

In contrast, Blumenberg's own perspective on the sciences-as he developed it first in The Legitimacy of the Modern Age, then The Genesis of the Copernican World, and also in numerous satellite essays-grows out of an investigation of the history of the "theoretical attitude" from the ancient philosophical curiositas to the modern, institutionalized sciences. Accordingly, Blumenberg's work brings into focus lasting continuities rather than ruptures between inquiry in the sciences and in the humanities. Not denying, but historicizing the Weberian premise of an existential loss

\footnotetext{
${ }^{8}$ Robert Buch and Daniel Weidner, ed., Blumenberg lesen: Ein Glossar (Berlin: Suhrkamp, 2013), introduction, esp. 16-20 ("Dimensions of legibility" ["Dimensionen der Lesbarkeit"]).

${ }^{9}$ Borck, "Begriffene Geschichte: Canguilhem, Blumenberg und die Wissenschaften," in Borck, Blumenberg beobachtet, 168-95, 179, outlines Blumenberg's criticism of Kuhn's model of paradigm change as too schematic. On the notion of paradigm, Blumenberg, "Paradigma, grammatisch," in Wirklichkeiten in denen wir leben (Stuttgart: Reclam, 1981), 157-62.

${ }^{10}$ On these largely implicit contexts, see Buch, "Curiosity" ["Neugierde"], in Buch and Weidner, Blumenberg lesen, 228-44, esp. 228-29.
} 
of orientation concomitant with the rise of the scientific and technological "mastery of nature," Blumenberg insists on the uniting element of a shared "theoretical attitude" betwen scientific and philosophical inquiry, and the humanities more widely—an "exotic behavior" linking Thales of Miletus with today's astronomers. ${ }^{11}$ This insistence is not without its own problems, but it offers a dimension for reading Blumenberg as a historian and philosopher of science and technology. It is an insistence that inquires, like much of Blumenberg's work, "not only into the hermeneutical meaning ...., but always also into the existential function of the products of the human intellect." 12

In this essay, I first historicize Blumenberg's own focus on this concept to explain its theoretical importance to his work. Second, I trace Blumenberg's emphasis on the continuity of the 'theoretical attitude' in his work on science. The posthumous publication of Blumenberg's anthropological writings, ${ }^{13}$ and of his writings on technology, ${ }^{14}$ which reinforce his understanding of technology as creative act, adds new facets to this concept. Building upon recent studies of Blumenberg's material writing practices, I foreground the role of his Zettelkasten as the site of developing his own theoretical attitude as a historian and philosopher. Blumenberg's nearobsessive reliance on this writing machinery has its conceptual counterpart in the importance of the notion of the "theoretical attitude" in his writings. His own, lifelong striving to develop such an attitude both materially and theoretically corresponds to his moral demand to develop a critical historical perspective on the shared origins of the sciences and the humanities, a perspective he diagnosed as fatally lacking in Germany's National Socialist years.

11 "Theorie als exotisches Verhalten," in Blumenberg, Das Lachen der Thrakerin: Eine Urgeschichte der Theorie (Frankfurt: Suhrkamp, 1987), 9-12. Translated into English by Spencer Hawkins as "Theory as Exotic Behavior," in Blumenberg, The Laughter of the Thracian Woman: A Protohistory of Theory (London: Bloomsbury, 2015), 1-4.

12 "Blumenberg [fragt] niemals nur nach dem hermeneutischen Sinn der Werke geistiger Kultur ...., sondern auch und vor allem nach ihrer existentiellen Funktion," Wetz and Timm, Kunst des Überlebens, 10.

${ }^{13}$ Blumenberg's anthropological writings, mainly an attempt to reconcile phenomenology with the tradition of philosophical anthropology, have been gathered in Blumenberg, Beschreibung des Menschen: Aus dem Nachlass, ed. Manfred Sommer (Frankfurt: Suhrkamp, 2006). This publication has led to a surge of reinterpretations of his work through the lens of these anthropological writings; see Rebekka A. Klein, ed., Auf Distanz zur Natur: Philosophische und theologische Perspektiven in Hans Blumenbergs Anthropologie (Würzburg: Königshausen \& Neumann, 2009).

${ }^{14}$ Blumenberg, Geistesgeschichte der Technik, ed. Alexander Schmitz and Bernd Stiegler (Frankfurt: Suhrkamp, 2009); Blumenberg, Schriften zur Technik, ed. Schmitz and Stiegler (Berlin: Suhrkamp, 2015). 


\section{BLUMENBERG'S ZETTELKASTEN AS A SYSTEM TO DEVELOP A THEORETICAL ATTITUDE}

Blumenberg's Zettelkasten has become a relic. It was featured in an exhibition on note card boxes at the Marbach Literature Archive, where "the entire Suhrkamp culture," of which Blumenberg was a prominent part, "had been bundled off to" by the early 2000s. ${ }^{15}$ Only Niklas Luhmann's collection matches Blumenberg's in size and importance to his writing process; he would presumably have shared Luhmann's dry description of visitors coming to see his "spirit in a box": "Spectators come. They get to see everything, and nothing but that-as in an adult movie. And are accordingly disappointed." 16

Ulrich von Bülow and Dorit Krusche have documented Blumenberg's elaborate method of systematically arranging excerpts from the vast variety of texts he read: "In Blumenberg's case, nearly all acts of reading, interpretation and ordering took material shape within the Zettelkasten." ${ }^{17} \mathrm{Blu}$ menberg's first collection of note cards dates back to the early 1940s but was lost during the war; the Marbach collection contains cards from 1947 onwards. ${ }^{18} \mathrm{He}$ would first underline relevant passages, and then copy some of those passages onto note cards, thus removing them from their context. After placing the note cards in a specific location within the Zettelkasten, he would add keywords or hierarchies of keywords, thereby producing new connections and classifications within the ever-growing collection of notes. Von Bülow and Krusche analyze this system as a medium of "conversation with oneself," where the Zettelkasten stands in for lacking or absent interlocutors. ${ }^{19}$ However, in the context of Blumenberg's anthropological writings, another dimension of the Zettelkasten's use becomes apparent. By

15 "Mittlerweile wurde die ganze Suhrkamp-Kultur ins [Marbacher] Archiv verfrachtet," Borck, Blumenberg beobachtet, 19.

16 "Zuschauer kommen. Sie bekommen alles zu sehen, und nichts als das-wie beim Pornofilm. Und entsprechend ist die Enttäuschung," as quoted in Jürgen Kaube, "Alles und noch viel mehr: Die gelehrte Registratur," Frankfurter Allgemeine Zeitung, March 6, 2013, http://www.faz.net/aktuell/feuilleton/geisteswissenschaften/zettelkaesten-alles-und -noch-viel-mehr-die-gelehrte-registratur-12103104.html.

17 "Bei Blumenberg haben nahezu alle Aspekte der Lektüre, der Interpretation und der Ordnung im Zettelkasten materielle Gestalt angenommen," von Bülow and Krusche, "Vorläufiges," 275.

${ }^{18}$ Von Bülow and Krusche, "Vorläufiges," 273.

19 "Selbstgespräch" (114), "Medium der Selbstkommunikation" (113), von Bülow and Krusche, "Nachrichten an sich selbst: Der Zettelkasten von Hans Blumenberg," in Zettelkästen: Maschinen der Phantasie, ed. Heike Gfrereis and Ellen Strittmatter (Marbach: Deutsche Schillergesellschaft, 2013), 113-19. 
producing and handling the notes, Blumenberg established and cultivated what he calls a Geschichtsverhältnis, or "relation to history." Such a relation requires attentiveness to the temporality and historicity of thought, and is a distinctive part of the "theoretical attitude" as it characterizes the historian and philosopher. In one of his many definitions of this notion so central throughout his work, Blumenberg describes the theoretical attitude as referring to the turn of human consciousness to the "conceptuality of things." ${ }^{20}$ As Blumenberg sees and performs it, the historian-philosopher's kind of theoretical attitude is to conceptualize historical reality.

A drawing found among Blumenberg's unpublished notes-a diagram of human consciousness titled "Reality check" [Realitätsprüfung]—visually renders this link between concept and material writing practices. ${ }^{21}$ The drawing resembles a textbook diagram of a reflex arc-a "black box $=$ soul" receives inputs from a "receptor" side and produces outputs through an "effector." Three thick arrows labeled $t$ indicate the time during which "perceptions occur which cannot be translated into directions for actions immediately. It is only their connection or constellation which confers to perception the character of the complex 'object.' "'22

Leaving aside the accuracy of Blumenberg's account of the biological evolution of the feature depicted in the diagram, his intention is to extend phenomenology's protest against an unproblematic immediacy of the perceived given by placing the role of passing time center stage. Consciousness does not cause the delay between input and output; rather, consciousness is that delay, or more precisely the "full-fledged form of its appearance." 23 This time-sink structure is remarkable insofar as it allows human beings to "act with reference to things not perceived"-things that may be distant spatially or temporally. ${ }^{24}$ The resulting "directions for actions" are the product of an accumulation of past inputs, and the establishment of new configurations among them. The transition criterion to the "possibility of

20 "Begrifflichkeit der Dinge," Blumenberg, Lachen der Thrakerin, 16 (emphasis in original); The Laughter of the Thracian Woman, 8.

${ }^{21}$ The drawing is reproduced in von Bülow and Krusche, "Vorläufiges," 275, where the authors draw attention to its relevance to Blumenberg's material working practices, and further discussed in Borck, Blumenberg beobachtet, 13-14.

22 "Es müssen Empfindungen auftreten, die nicht oder nicht sogleich in Handlungsanweisungen umgesetzt werden können und deren Verbindung oder Konstellation erst in die Wahrnehmung den Charakter des komplexen 'Gegenstandes' einbringt," Blumenberg, Beschreibung des Menschen, 558.

23 "Ausgeschöpfte Erscheinungsform," Blumenberg, Beschreibung des Menschen, 560.

24 "An Gegenständen [handelt], die [es] nicht wahrnimmt," Blumenberg as quoted in Klein, Auf Distanz, 9; Blumenberg, Theorie der Unbegrifflichkeit, ed. Anselm Haverkamp (Frankfurt: Suhrkamp, 2007), 10. 
the human," the only acceptable replacement for the impossible, atemporal question of the "essence of the human" to Blumenberg, is marked by the active formation of "connections and constellations" stretched out over time. $^{25}$

Blumenberg himself invites the extension of this discussion of object formation and direction for action from allegedly basic physiological processes along increasing degrees of deliberation to full-fledged theorizing since the basic mechanism implies that humans are "creatures equipped, at least, for theory." 26 The phenomenological-anthropological description of the role of time in object formation has its methodological counterpart in the "theoretical attitude." Blumenberg's own writings exemplify both the textual products that can result from this theoretical attitude and the process of establishing "connections and constellations." Analogous to consciousness being the delay between input and output, the process of "theorizing" is this establishment of connections, as reflected both materially and spatially within the Zettelkasten, and conceptually not in "directions for actions" but texts. "Working up of the temporal dimension of our orientation in reality," for Blumenberg, requires orientation with respect to stacked and complex conceptual legacies. ${ }^{27}$ If individual human consciousness is the ability to act with reference to things not acutely perceived, historical deliberation brings into focus "things" from a past long before the individual's lifetime: layered stories, arguments, artifacts. Preceding any specific historiographical method, the Zettelkasten provides the space in which potential constellations between these things can appear concretely, a space to play with connections as they have been formed by historic predecessors or might be formed in the present.

The cultivation of this relation to history is, to Blumenberg, necessary for appreciating the contingencies that characterize human thought above all else. The non-simultaneity of physical appearances in the present, he argues, is a simple consequence of the finite speed of light. This physical fact is a paradigm for historical reality: "Presence cannot enable us to apprehend the necessity of what is given in it, because it is only an accidental section through reality. The irregularity of appearances in space turns out to be a projection of the fateful delays onto the plane of what is just

\footnotetext{
25 "Die Frage, wie der Mensch möglich sei," Klein, Auf Distanz, 13.

26 "Ein auf Theorie zumindest vorbereitetes Wesen," Blumenberg, Beschreibung des Menschen, 560.

27 "Aufarbeitung der Zeitdimension unserer Wirklichkeitsorientierung," Blumenberg, Die Genesis der kopernikanischen Welt (Frankfurt: Suhrkamp, 1975), 149. Translated into English by Robert Wallace as The Genesis of the Copernican World (Cambridge, MA and London: MIT Press, 1987), 123.
} 
now visible; it is a paradigm for the distortion of reality by time, not only, and not most painfully, in nature but also in history." ${ }^{28}$

The philosopher-historian's work is not a matter of removing those distortions that are inherent to historical reality, but of the "disciplining of attentiveness" 29 necessary to perceive and describe its complex temporal structure and its multiple contingencies, and thus to develop a historically informed perspective on the presently given rather than "succumbing to it." ${ }^{30}$ The upshot of this attitude is the historical equivalent to Blumenberg's anthropological notion of reality, which, in Rebekka Klein's words, “orients human consciousness not with respect to acute or present reality, but with respect to its contingency, its possibility to be or become different." ${ }_{11}$ Although it cannot change past reality, it can retrospectively clarify the spaces for different possible actions or outcomes.

Just as the methodological choice to write his historical-philosophical works in terms of conditions of possibilities and counterfactuals corresponds to the demand of articulating contingencies, ${ }^{32}$ the emotionally charged vocabulary of "painful distortions" and "fateful delays" in describing the effect of time is not a coincidence. If the "reality check" is his marker of the human, Blumenberg describes the cultivation of a historically informed critical attitude as distinct from, but a prerequisite for, responsible humane action. He made the importance of these concerns clear in his 1961 speech at the reopening of the philosophical faculty at Giessen University. There Blumenberg portrayed the task of "articulating [historical] contingencies" as "preliminaries to a moral problem." $\mathrm{He}$ said, "We have to know what we are doing in order to be able to ask whether it is what we should be doing. The relation between knowing

28 "Die Irregularität der Erscheinungen im Raum erweist sich als die Projektion der fatalen Verspätungen auf die Ebene des gerade Sichtbaren; sie ist das Paradigma für die Verzerrung der Wirklichkeit durch die Zeit, nicht nur und nicht am schmerzhaftesten in der Natur, sondern auch in der Geschichte," Die Genesis der kopernikanischen Welt, 125; Blumenberg, The Genesis of the Copernican World, 103.

29 "Disziplin der Aufmerksamkeit," Blumenberg, Wirklichkeiten, 5.

30 "Aber daß wir unsere Geschichte und uns in dieser Geschichte verstehen wollen, bedeutet auch, daß wir uns dem Vorgegebenen nicht unterwerfen, daß wir unsere Bedingtheiten nicht blind hinnehmen, sondern zur Sprache bringen müssen," Blumenberg, "Weltbilder und Weltmodelle," in Schriften zur Technik, 126-37, esp. 127-28.

31 "Der das menschliche Bewusstsein nicht an der akuten und gegenwärtigen Wirklichkeit orientiert, sondern an ihrer Kontingenz, ihrer Möglichkeit, anders zu sein oder zu werden," Klein, Auf Distanz, 10.

${ }^{32}$ On this style, see Philipp Stoellger, "Vom Denkstil zum Sprachstil: Von Fleck zu Blumenberg-und zurück," in Borck, Blumenberg beobachtet, 196-228, esp. 224-28. 
and what we should be doing has become more complicated than it appeared to Socrates." 33

The historical development of the sciences is his primary concern in this context. In the brief allusion to Socrates, Blumenberg hints at the legacy of the association of virtue with knowledge that has left its traces in a problematic misunderstanding of the role of the modern sciences. To him, the modern sciences, as opposed to their earlier, more metaphysically invested predecessors, are "autonomous" in the sense that they do not contain elements of pragmatic use for human self-orientation or self-understanding within a scientifically described reality. They do not, in his terminology, produce a "world picture" which does contain such elements (a usage of "world picture" that differs from Heidegger's- he uses the term for an understanding of the world as the totality of what can be objectified, and associates it with the modern sciences). ${ }^{34}$ Instead they produce "world models," representations of empirical reality that are continously updated as science progresses but, unlike a "world picture," have no "practical force, as Kant would have put it." 35

But, crucially for Blumenberg, a sufficient degree of association with elements for moral guidance and orientation has remained for the "world model to take the place of the world picture," for attempts to extract "metaphysical guidelines" from the sciences. ${ }^{36}$ A significant part of his speech emphasizes how the institutional separation of the modern sciences and philosophy is a historical process stemming from a continuous intellectual tradition. This historical perspective on the sciences is the decisive prerequisite, Blumenberg stresses, to recognize the lasting association of scientific results with normative guidance both as a plausible temptation and as a mistake. The urge for this recognition results from witnessing the political conclusions of biological racism (a point Blumenberg makes without mentioning his personal experience $)^{37}$ : from the translation of a Darwinian world model, "containing nothing regarding the question of human

\footnotetext{
33 "Das ist ... der Vorspann aller moralischen Problematik. Wir müssen wissen, was wir tun, um uns fragen zu können, ob es das ist, was wir tun sollen"; "Bedingtheiten . . . zur Sprache bringen," Blumenberg, "Weltbilder und Weltmodelle," 127, 128.

${ }^{34}$ Martin Heidegger, "Die Zeit des Weltbildes," in Holzwege (Frankfurt: Klostermann, 1950), 75-114, esp. 89.

35 "Das Weltbild hat 'praktische Kraft,' wie Kant gesagt hätte," Blumenberg, "Weltbilder und Weltmodelle," 129.

36 "In Wirklichkeit war es so, daß das 'Weltmodell' die Stelle des 'Weltbildes' besetzte"; "um ... metaphysische Leitbilder zu gewinnen," Blumenberg, "Weltbilder und Weltmodelle," Technik, 131.

${ }^{37}$ On Blumenberg's life under National Socialism and its reverberations in his later rela-
} 
self-understanding, of what humans may or should do," into a Fascist world picture "with truly fatal consequences." 38

The same urge informs Blumenberg's understanding of the activity of the philosopher-historian kind of theoretician. The aim of cultivating "history as a theoretical attitude" remains theoretical. It is to "keep our concept of the world in check by theoretical responsibility," resulting in an immunity to ideological "seduction." ${ }^{39}$ This analysis is construed in opposition to the public role of the philosopher as proclaimed by Martin Heidegger, most loudly in another opening speech, the 1933 Rektoratsrede.$^{40}$ Heidegger's vision of the "Denker als Handelnder," the "thinker as acting person," had its origins in his turn toward Seynsgeschichte concomitant with his turn toward National Socialism. ${ }^{41}$ As with much of Heidegger's writing since Being and Time, which Blumenberg, in 1987, calls "still the most important philosophical treatise of the century" despite his sharp disagreements with Heidegger's later work, he does not deem this position worthy of explicit comment. ${ }^{42}$ However, he clarifies his refusal to give up the distinction between theory and practical action elsewhere, namely in his discussion of the notion of the "theoretician as perpetrator," Täter. Historicizing the metaphor, he explains its appeal as a stylization of the figure of the astronomer and mathematician. Copernicus, Galilei, and Bruno are among those whose theoretical insights have been understood as practical acts. The metaphor of the theoretician as perpetrator responds to the "great modern need to see concepts as guarantors of reality-to realize the idea, which was invested in the medieval conception of the Divinity, that thought as such, and without delay, could determine (if not, in fact,

tion to his home town Lübeck, see Ada Kadelbach, “ 'Missachtung' und 'Versöhnungsversuch': Hans Blumenberg und Lübeck," in Blumenberg beobachtet, 254-71.

38 "Darwins theoretisches Modell . . . enthielt . . . nichts darüber, wie der Mensch sich selbst zu verstehen hat, was er tun durfte oder tun sollte. Aber in ein 'Weltbild' übersetzt . . . wurde daraus der krasseste Biologismus mit seinen wahrhaft verhängnisvollen Konsequenzen," Blumenberg, "Weltbilder und Weltmodelle," 134-35.

39 "Unsere Weltvorstellung . . . unter der Kontrolle theoretischer Verantwortung zu halten," "Bildung ist ganz wesentlich Unverführbarkeit," Blumenberg, "Weltbilder und Weltmodelle," 136.

${ }^{40}$ Blumenberg calls this speech Heidegger's "most unfortunate hour" [unglücklichste Stunde] in Lachen der Thrakerin, 11; The Laughter of the Thracian Woman, 2.

${ }^{41}$ For a detailed account of Heidegger's philosophy as he presented it, from the early 1930s onward, as the "essential act of human Dasein," see Marion Heinz, "Politisierung der Philosophie: Heideggers Vorlesung 'Welt, Endlichkeit, Einsamkeit' (WS 1929/30)," in Philosophie und Zeitgeist im Nationalsozialismus, ed. Marion Heinz and Goran Gretić (Würzburg: Königshausen \& Neumann, 2006), 269-90, at 278.

42 "Noch immer bedeutendste[s] philosophische[s] Werk dieses Jahrhunderts," Blumenberg, Ein mögliches Selbstverständnis (Stuttgart: Reclam, 1996), 159. 
produce) the world. Consequentially the history of this Copernican metaphor is a history of the most welcome confusions between theory and practice: that theory, if indeed it cannot be practical, might at least be an assurance of the possible effects of thought on action too." ${ }_{43}$ If Heidegger is among those instrumentalizing this confusion, Blumenberg, in contrast, insists on the phenomenological understanding of history and philosophy as "descriptive technique," aiming to offer as clear a description of temporally structured reality as possible. ${ }^{44}$ To the extent that this activity can be construed as a "role" (despite Blumenberg's warning against an overreliance on the fixity of "roles" as presupposed by the "solid tradition of representing life and world as theater"), ${ }^{45}$ he restricts it to that of the theoros, the spectator.

\section{THE THEORETICAL ATTITUDE AS AN ELEMENT OF CONTINUITY BETWEEN DIFFERENT FORMS OF INQUIRY}

Turning away for now from Blumenberg's writing practices as a materialization of the theoretical attitude, let me discuss this attitude as an element of continuity between knowledge of self and knowledge of the world or, in its modern version, between the humanities and the sciences, as he portrays them in his two major works on the emergence of early modern science, The Legitimacy of the Modern Age and the The Genesis of the Copernican World, and in some of his essays. In Legitimacy, the origins of modern science are explicitly investigated as the rehabilitation of ancient curiositas, the theoretical attitude; in Genesis, a shift of emphasis to scientific inquiry as an act of human self-affirmation calls into question the hermeneutical meaning of this kind of inquiry as opposed to a merely instrumental, Baconian view of its role.

\footnotetext{
43 "Eines großen neuzeitlichen Bedürfnisses, den Begriff als Garanten der Wirklichkeit zu sehen, die in den mittelalterlichen Entwurf der Gottheit investierte Idee zu realisieren, der Gedanke könne als solcher und ohne Aufenthalt die Welt bestimmen, wenn nicht gar erzeugen," Die Genesis der kopernikanischen Welt, 340; Blumenberg, The Genesis of the Copernican World, 289.

44 “Deskriptives Verfahren," Blumenberg, Wirklichkeiten, 5.

45 "Solide Tradition, Leben und Welt als 'Theater' zu veranschaulichen," Blumenberg, “Anthropologische Annäherung an die Rhetorik," in Wirklichkeiten, 104-36, at 118. Cf. Hans Blumenberg, "An Anthropological Approach to the Contemporary Significance of Rhetoric," in After Philosophy: End or Transformation?, ed. Kenneth Baynes, James Bohman, and Thomas McCarthy (Cambridge, MA: MIT Press, 1987), 429-58, at 441.
} 
Legitimacy is mainly read as an intervention in the secularization debate in the wake of, most prominently perhaps, Karl Löwith. Blumenberg argued against understandings of a variety of modern ideas ranging from political egalitarianism to science as secularized versions of medieval Christian culture and against the resulting delegitimization of these ideas as merely borrowed. The book's third and longest part, "The Trial of Theoretical Curiosity," tracks the change in status of the theoretical attitude:46 "There arises in the modern age an indissoluble link between man's historical self-understanding and the realization of scientific knowledge as the confirmation of the claim to unrestricted theoretical curiosity." ${ }^{47}$ Blumenberg follows the articulations of this claim to an "unrestricted theoretical curiosity" alongside its counterpositions from an ideal-typical beginning in the opening sentence of the Aristotelian metaphysics, presenting it as an essential human characteristic: "All men by nature desire to know." Often associated with eudamonia, or the qualities of the good life, the claim to unrestricted curiosity is also from the outset contested as ridiculous (as manifested in the Thracian woman's laughter) or as frivolous (as in Cicero's privileging of the practically relevant). The new, modern link between historical self-understanding and curiosity is a turn against medieval Christian disqualifications of theoretical curiosity. In Augustine's influential view, the idea of happiness had been transferred to belief and disassociated from theoretical knowledge, portrayed as both arrogance and a waste of preciously limited human time better devoted to concern with salvation. The modern historical self-understanding appears as a choice to oppose this disqualification, removing the negative connotation. The positive one, however, is not restored. The disassociation of theoretical knowledge and the promise of happiness remains, lastingly removing this pragmatic function of the theoretical attitude.

This perspective on the changing status of the theoretical attitude has its problems, among them Blumenberg's disregard for curiosity's material rather than theoretical manifestations in institutions such as the Kuriositätenkabinette, or his downplaying of playful curiosity and sacrilegious forms of knowledge in medieval times for the sake of aligning them more closely

\footnotetext{
${ }^{46}$ Buch, "Curiosity," 232-35.

47 "Entsteht in der Neuzeit ein unauflösbarer Zusammenhang zwischen dem geschichtlichen Selbstverständnis des Menschen und der Realisierung von wissenschaftlicher Erkenntnis als der Bestätigung des Anspruches auf unbeschränkte theoretische Neugierde," Legitimität der Neuzeit. Erneuerte Ausgabe (Frankfurt: Suhrkamp, 1996), 267. Translated into English by Wallace as The Legitimacy of the Modern Age (Cambridge and London: MIT Press, 1983), 232.
} 
with the theoretical attitude. ${ }^{48}$ But, and crucially for my point here, what is importantly new about the new science for Blumenberg is the establishment of a connection with the much older attitude of theoretical curiosity, not the new science's alleged methodological break with older forms of inquiry as asserted by some of its practitioners and emphasized in some accounts of a scientific "revolution." In presenting the sciences as the rehabilitation of curiositas, Legitimacy asserts a firm connection despite the profound differences between the contemplative form of theoretical curiosity associated with ancient philosophy, and its experimental, manipulative forms associated with the new philosophy, science.

In Genesis-published in 1975, nine years after the first publication of Legitimacy, but in the midst of that earlier work's revision and republication from 1973 through 1976-Blumenberg's methodological premise is the necessity of explaining the history of science in conjunction with that of other ideas and practices, here primarily philosophical and religious, rather than accepting a division of those intellectual domains (a point Robert Wallace draws attention to in the preface to his English translation ${ }^{49}$ and that has since been described as an instance of Blumenberg anticipating historiographic developments well in advance of their becoming mainstream). ${ }^{50} \mathrm{His}$ emphasis is on the deep embeddedness of early modern astronomical and physical thought in metaphysical frameworks, and its very gradual disintegration. Copernicus, by making the earth turn around the sun, was far from putting an end to the idea that the physical universe may contain cues as to man's metaphysical position in it. The connection he established between this position and a spatial one, however, was subtler than the retrospective reading of Copernicus as having expelled humanity from a privileged cosmological centre. For Blumenberg's Copernicus, the human ability to understand the physical universe established man's privileged position in it. Some three hundred years later, Heinrich Heine can poetically mock the idea that the natural world could have been thought of as anything other than utterly indifferent to human needs and desires for meaning. Blumenberg does not fail to quote him, from On Ludwig Börne: "And thus I flew from one star to another. Aren't populated worlds though as others dream, just shiny spheres of rock, barren and bleak. They do not fall down since

\footnotetext{
${ }^{48}$ Buch, "Curiosity," 239; Lorraine Daston, "Die Lust an der Neugier in der frühneuzeitlichen Wissenschaft," in Curiositas: Welterfahrung und ästhetische Neugierde in Mittelalter und früher Neuzeit, ed. Klaus Krüger (Göttingen: Wallstein, 2002), 147-75, esp. 152-54.

${ }^{49}$ Blumenberg, The Genesis of the Copernican World, ix.

${ }^{50}$ Buch and Weidner, Blumenberg lesen, 21.
} 
they do not know what they might fall upon. Float around up there in great embarrassment." ${ }^{51}$ One possible reaction to this view of nature's indifference to human needs and its "genuine meaninglessness" was what Nietzsche called the lasting "anthropomorphism in the relation to nature": its very "meaninglessness [can] nevertheless clarify such a thing as the human 'position in the world," " namely the need both to create meaning and to fulfill material needs. In this light, Blumenberg can portray the new sciences and their transformation of the theoretical attitude as both a Baconian instrument for securing one's livelihood ${ }^{52}$ and as part of a broader process of theoretical human "self-assertion," gradually assumed in the face of the "doubt regarding the existence of a structure of reality that can be related to man" (as he had put it in Legitimacy). ${ }^{53}$

The perspective on early modern science as developed in those two broad studies informs Blumenberg's later writings by keeping the focus on a lasting tension between new experimental methods, instruments, and increasingly institutionalized forms of scientific inquiry, and the historical rootedness of that scientific inquiry in the "theoretical attitude." Critical as Blumenberg is of the modern, institutionalized sciences as characterized by the "immanence of the technical process"- their questions being generated through an institutionalized "autonomy just as impressive as it is alarming" ${ }^{4}$ - he at the same time resists their reduction to "instrumental reason" or to a totalizing objectifying method. One mode of this resistance is his assertion of the lasting importance of a "theoretical attitude," discussed in many of his later essays and collections. The Laughter of the Thracian Woman (1987) opens with the claim that even the modern astronomer, hidden away in an institutional shell, avoiding any clashes between his exotic doings and the surrounding world, can be seen as representing a theoretical attitude despite the fact that what he does practically is operate machinery: "Even if they produce no 'theory' as aggregates of propositions,

\footnotetext{
51 "Und so flog ich von einem Stern zum andern. Sind aber keine bevölkerten Welten, wie andere träumen, sondern nur glänzende Steinkugeln, öde und fruchtlos. Sie fallen nicht herunter, weil sie nicht wissen worauf sie fallen können. Schweben dort oben auf und ab, in der größten Verlegenheit," Blumenberg, Die Genesis der kopernikanischen Welt, 87; Blumenberg, The Genesis of the Copernican World, 71.

${ }^{52}$ On this point, see Benjamin Lazier, "Overcoming Gnosticism: Hans Jonas, Hans Blumenberg, and the Legitimacy of the Natural World," Journal of the History of Ideas 64, no. 4 (2003): 619-37.

${ }^{53}$ Blumenberg, Legitimacy, 137.

54 "Diese Institution hat eine ebenso eindrucksvolle wie beängstigende Autonomie," Blumenberg, Die Genesis der kopernikanischen Welt, 160; Blumenberg, The Genesis of the Copernican World, 133.
} 
the transitive sense of the Greek theoria authorizes us to think of them as constantly at work on theory." ${ }_{55}$

Blumenberg expands on the manifestations of the theoretical attitude in other essay collections. Die Vollzähligkeit der Sterne (The completeness of the stars, 1997) articulates the lasting ambivalence of scientific inquiry among that attitude, practical utility, and worldly institutional entanglements. In the essay "More planets or less pain?," Blumenberg quotes Georg Christoph Lichtenberg's reaction to William Herschel's 1781 discovery of Uranus: "Inventing an unfailing means against toothache, curing it instantly, would be well worth as much and more than discovering another planet." For Blumenberg, this Sudelbuch sentence "belongs to those most worthy of admiration among the sentences that have been written." ${ }^{56}$ Why is that? Because in the choice between "two irrealities" 57 Lichtenberg chooses the fulfillment of an immediate need, of curing pain. This is not an easy choice but one made "in brave sobriety"; after all, Lichtenberg, who "also dreamt, just a little bit, the discoverer's dream," was not the first to spot Uranus himself. ${ }^{58}$ Blumenberg has little patience for the pathos of scientific discovery; whether it regards Uranus or twentieth-century lunar travel, he is suspicious of any exaggeration of their necessity as likely instrumentalized by the interested few. ${ }^{59}$ But he grants Lichtenberg to have had a choice more difficult to make. Being a "creature born to watch the heavens" (Himmelsbetrachterwesen von Gebliut, about the closest Blumenberg comes to endorsing the Aristotelian essentializing definition), he nevertheless chooses to prioritize the immediate bodily need. ${ }^{60}$ The astronomer Lichtenberg embodies both theoretical attitude and instrumental reason; and in Blumenberg's view, the choice to prioritize the latter is admirable.

\footnotetext{
55 "Auch wenn er keine Theorie als Aussagenkomplex produziert, ermächtigt der transitive Sinn der griechischen theoria dazu, ihn unausgesetzt bei dieser am Werk zu denken," Blumenberg, Lachen der Thrakerin, 9-10; Blumenberg, Laughter of the Thracian Woman, 2.

56 "Ein untrügliches Mittel gegen das Zahnweh zu erfinden, wodurch es in einem Augenblick gehoben würde, möchte wohl so viel wert sein und mehr, als noch einen Planeten $z u$ entdecken. Dieser Satz ... gehört für mich zu den bewunderungswürdigsten, die geschrieben worden sind," Blumenberg, "Mehr Planeten oder weniger Schmerzen?," in Die Vollzähligkeit der Sterne (Frankfurt: Suhrkamp, 1997), 187-90, at 188.

57 “Zwei Irrealitäten,” Blumenberg, "Mehr Planeten oder weniger Schmerzen?," 189.

58 "In seiner tapferen Nüchternheit," "Lichtenberg . . . träumte auch ein wenig den neuen Entdeckertraum," Blumenberg, "Mehr Planeten oder weniger Schmerzen?," 188.

${ }^{59}$ See the essay "Nachdenklichkeit als Bedenklichkeit," in Blumenberg, Die Vollzähligkeit der Sterne, 320-24.

${ }^{60}$ Blumenberg, "Mehr Planeten oder weniger Schmerzen?," 189.
} 
In "collaboration with his Zettelkasten," ${ }^{11}$ Blumenberg worked to portray these tensions between different and changing historical meanings of scientific inquiry. Attention to the voices articulating the exception to the rule is important for a writer seeking, above all, to spell out the "opening for the possibility" of historical change-openings framed largely, but far from exclusively, in conceptual terms. Dissent and alternatives mark the scope, or more lightly Spielraum (literally "room to play"), in which this contingent process unfolds. ${ }^{62}$ To the extent that Blumenberg operates with categories such as an era's "metaphysical need," they are instantiated also in their negation; while his is a history of broad changes, the rhetorical function of allegedly descriptive terms such as "scientific revolution" is what interests Blumenberg, constantly seeking to elucidate their relation to historical actors and historians alike. ${ }^{63}$ Counterfactuals play an equally important role in this style of argument. Compare, for example, Blumenberg's question whether it is "too bold to claim that the airplane is anchored deeply enough in the immanence of the technical process that the day of Kitty Hawk would have come even if no bird had ever taken to the skies?" ${ }_{64}$ to the opening of Genesis, in which Blumenberg reiterates Henri Poincaré's question of whether there could ever have been a Copernicus if too thick a layer of clouds prevented humans from seeing the starry sky. ${ }^{65}$ The different answer to both questions indicates the difference Blumenberg sees between the science of the days of Copernicus and those of of the Wright brothers. Copernicus's work four hundred years earlier could not be separated from a metaphysical assumption, that of the visibility of the reality under scientific investigation-the very assumption that his results eventually undermined, leaving a lasting gap between reality as perceived by the human senses and as described theoretically.

\footnotetext{
${ }^{61}$ As put in von Bülow und Krusche, "Nachrichten," 113: "Zusammenarbeit mit seinem Zettelkasten."

${ }^{62}$ The title of the second part of the Genesis is "The opening up of the possibility of a Copernicus." On the connection between Blumenberg's writing style and argumentative style in more depth, see Stoellger, "Vom Denkstil zum Sprachstil," esp. 210 and 226.

${ }^{63}$ See, for example, his discussion of the term "Copernican Turning" as not used by Kant: Blumenberg, The Genesis of the Copernican World, part 5, chap. 5 ("What is "Copernican' in Kant's Turning?").

64 "Ist es etwa zu kühn, wenn man behauptet, daß das Flugzeug so in der Immanenz des technischen Prozesses darinsteht, daß es auch dann zu dem Tage von Kitty Hawk gekommen wäre, hätte nie ein Vogel die Lüfte belebt?" Blumenberg, "Nachahmung der Natur: Zur Vorgeschichte der Idee des schöpferischen Menschen," in Wirklichkeiten, 55-103, at 61; cf. " 'Imitation of Nature': Toward a Prehistory of the Idea of Creative Being," trans. Anna Wertz, Qui parle 12, no. 1 (2000), 17-54, at 22.

${ }^{65}$ Blumenberg, The Genesis of the Copernican World, 3.
} 
Blumenberg's willingness to praise practical benefits and comforts brought about by the modern sciences distinguishes his tone from that of interlocutors such as Adorno and Horkheimer or Heidegger, but it should not be confused with an uncritical perspective. In keeping with his refusal to endorse the "sharp separation of history and nature, which is nothing but an explication of the Cartesian difference between thinking and extended substance," ${ }_{66}$ Blumenberg's position does not entail an epistemic privilege for the sciences, lending legitimacy to scientific statements by virtue of their reference to empirical reality. The character of scientific statements is necessarily rhetorical in the sense that "history of science showed in detail how verification, too, represents the pattern of agreement subject to later revocation, and how the publication of every theory implies a request that other people should follow the paths by which the theorist claims that it is confirmed and should give it the sanction of objectivitywithout it ever being possible to exclude, by this process, the possibility that by other paths other things may be discovered and the theory contradicted." ${ }^{67}$ This view, resulting from a conceptual history of the relation between rhetorics and philosophy, converges with Kuhn's as developed through the study of the sociological aspects of scientific practice: "What Thomas S. Kuhn in The Structure of Scientific Revolutions called the 'paradigm' . . . is nothing but a consensus, which is able to stabilize itself not, indeed, exclusively, but partly by means of the rhetoric of the academies and the textbooks"-consensus being the "ideal of rhetorics" as opposed to a philosophical striving for certainty, which Descartes might perhaps still have endorsed but which appeared increasingly untenable in step with the transformation of philosophy "into a theory of the scientific 'method' of the modern age." ${ }^{68}$ From this rhetorical perspective, science appears as one of the many varying human means to deal with the unavailability of truth.

66 "Mit der scharfen Trennung von Geschichte und Natur, die nichts anderes ist als die Explikation der cartesianischen Denkfigur von denkender und ausgedehnter Substanz," Die Genesis der kopernikanischen Welt, 88; Blumenberg, The Genesis of the Copernican World, 71.

67 "Die Geschichte der Wissenschaft gab Aufschluß darüber, daß auch Verifikation den Typus der Zustimmung auf Widerruf repräsentiert, daß die Publikation jeder Theorie einen Appell impliziert, die angegebenen Wege ihrer Bestätigung nachzugehen und ihr das Placet der Objektivität zu geben, ohne daß durch diesen Prozeß je endgültig ausgeschlossen werden kann, daß auf anderen Wegen anderes gefunden und Widerspruch erhoben wird," Blumenberg, "Anthropologische Annäherung an die Rhetorik," 112; Blumenberg, "An Anthropological Approach to Rhetoric," 436.

68 "Das, was Thomas S. Kuhn in seiner Struktur wissenschaftlicher Revolutionen das "Paradigma" genannt hat, ... ist nichts anderes als ein consensus, der sich zwar nicht ausschließlich, aber auch über die Rhetorik der Akademien und der Lehrbücher zu stabilisieren vermochte"; "Umwandlung in eine Theorie der wissenschaftlichen "Methode" der 
Blumenberg's opposition to a reductive view of science extends to his work on technology as well. ${ }^{69} \mathrm{~A}$ race car aficionado and member of the "Philosophy and Technology" committee in the Verein Deutscher Ingenieure, the largest and most important association of the engineering profession in Germany, Blumenberg proclaimed that many of the twentieth-century critiques of technology made him "wish to hear the word 'technology' out of the mouth of technical practitioners alone." ${ }^{70}$ In keeping with his rooting of the history of the sciences in the long-term development of a theoretical attitude, he offers a historical account of technology as an articulation of human creativity rather than domination of nature, a move that is in keeping with his own reliance on the Zettelkasten as a piece of writing machinery integral to the active and creative development of critical historical-philosophical thought. In Blumenberg's diagnosis, the spectrum of technology criticism (ranging from a vague and ill-articulated sense of discomfort with technology to Husserl's portrayal of it as a "pathological phenomenon," and Heidegger's stylization as a deep metaphysical threat ${ }^{71}$ is the result of a lack of conceptual space to legitimately articulate human technical creativity; a problem Blumenberg describes as the "speechlessness of technology" in contrast to the artistic and poetic repertoire of selfpresentation. ${ }^{72}$ In opposing these views, Blumenberg does share some of Husserl's uneasiness with "technicisation," as part of the broader process

Neuzeit," Blumenberg, "Anthropologische Annäherung an die Rhetorik," 112; Blumenberg, "An Anthropological Approach to Rhetoric," 436.

${ }^{69}$ For an overview of the different facets of Blumenberg's writings on technology since its discussion in the context of the Legitimacy as a means of self-assertion in the face of metaphysical or theological "absolutes," and as they have become apparent with the posthumous publication of the Geistesgeschichte der Technik (2009) and Schriften zur Technik (2015), see Ernst Müller, “Technik," in Blumenberg lesen, ed. Buch and Weidner, 323-36, and for a more detailed account of the development of his reflections on technology, turning away from his early views as influenced by Heidegger, see Oliver Müller, "Natur und Technik als falsche Antithese: Die Technikphilosophie Blumenbergs und die Struktur der Technisierung," Philosophisches Jabrbuch 115 (2008): 99-124. For a broader situating of his writings of technology, see also Tim-Florian Goslar and Christian Voller, "Geistesgeschichte der Technik als 'Kritik der Fortschrittskritik': Editorischer Kommentar," Zeitschrift für Kulturphilosophie 2 (2013): 423-29.

70 “Man [möchte] das Wort 'Technik' nur noch aus dem Munde des Technikers hören," Blumenberg, "Lebenswelt und Technisierung unter Aspekten der Phänomenologie," in Wirklichkeiten, 7-54, at 9. Including a picture of her father at the steering wheel: Bettina Blumenberg, "Eine Frage der Belichtung: Über den Philosophen Hans Blumenberg," Neue Zürcher Zeitung, July 13, 2015, accessed January 5, 2016, http://www.nzz.ch/ feuilleton/buecher/eine-frage-der-belichtung-1.18578697.

71 "Pathologisches Phänomen," Blumenberg, "Lebenswelt und Technisierung," 40.

72 “ 'Sprachlosigkeit' der Technik," Blumenberg, "Nachahmung der Natur,” 60. 
of modern "theorization" that Husserl largely associates with the mathematicized sciences, to the extent that it is a transformation involving "a forfeit of self-understanding and self-responsibility." ${ }^{73}$ But as in the case of the sciences, Blumenberg resists such criticism when it appears as reductive of its target, and as constructing an opposition between technological creation (as well as scientific inquiry) and historical-philosophical reflection upon it. ${ }^{74}$

Rather than the history of technological artifacts, Blumenberg's interest is the historical process of technicization. The two influential early essays, "Life-World and Technicization" and "Imitation of Nature," connect this process with that of human "self-assertion." 75 Emphasizing the perception of not being provided by "nature" as a distinctly modern phenomenon, Blumenberg argues that the prerequisite for modern technology is a new "differentiation of the ways of viewing the given," 76 an argument that goes hand in hand with his insistence on the need to historicize any philosophical-anthropological characterization of humans as deficient beings, Mängelwesen, from Herder to Gehlen. ${ }^{77}$ To characterize the new, and ambivalent, perception of the given, he borrows from Paul Valéry's discussion of the metaphor of nature as an abyss: it may appear as a threat to be avoided, but also as a potential for change—as "resistance" but also as a "cry for bridges." 78

Accordingly, Blumenberg describes the modern process of "technicization" as the historical unfolding of a conceptual mistake, of the false antithesis of "nature" versus "technology." Deep as its begriffsgeschichtliche roots may be, he argues, the opposition of "nature" as the sum of the

73 "Einbuße an Selbstverständnis und Selbstverantwortung," Blumenberg, "Lebenswelt und Technisierung," 40.

${ }^{74}$ In contrast, see Jürgen Goldstein, "Entfesselter Prometheus? Hans Blumenbergs Apologie der neuzeitlichen Technik," in Borck, Blumenberg beobachtet, 25-46, emphasizing what he sees as the "apologetic" aspects of Blumenberg's work on technology.

${ }^{75}$ First published in 1963 and 1957, both essays are reprinted in Blumenberg, Wirklichkeiten: "Lebenswelt und Technisierung unter Aspekten der Phänomenologie," 7-54, “'Nachahmung der Natur:' Zur Vorgeschichte der Idee des schöpferischen Menschen,” 55-103. See Anna Wertz, "On the possibility of creative being: Introducing Hans Blumenberg," Qui parle 12, no. 1 (2000): 3-15.

76 "[Differenzierung] auf der Basis der Anschauung des Gegebenen," Blumenberg, "Lebenswelt und Technisierung," 7.

77 Blumenberg, The Genesis of the Copernican World, 70; Blumenberg, "Lebenswelt und Technisierung," 8, 16; Blumenberg, Legitimacy, 152. On this point, see Goldstein, "Entfesselter Prometheus," 28-31.

78 "Es gibt nicht nur die Natur, die sich der Technik widersetzt, ... sondern . . . auch die Natur, die wie ein Schrei nach dem Zügel und Zaum des Menschen ist, . . . nach Brücken," Blumenberg, "Lebenswelt und Technisierung," 7-8. 
given and human technology as its exploitation and domination neglects the possible alternative of a continuity between "nature" as creative principle and human, technical creation. ${ }^{79}$ His favorite example to illustrate the contingency of this process is Nicholas of Cusa's spoon-maker (the corresponding note card would have been struck through in red many times). In 1450 , he draws his self-esteem from his technical creation, the carved-wood spoon. The spoon is a genuinely creative product in that it does not have a precedent in nature-but making the spoon is a creative process only in imitation of divine creativity. This move combines a pride in human creative power with a theological-metaphysical legitimation that avoids the rhetorical pathos of the stark opposition of the natural and the man-made. In that avoidance, it is a rare exception to the rule of "human creativity seeing its space of action restricted by the given." ${ }^{80}$ So as to preserve the self-image of genuine creativity as it results from the original conceptual mistake, "producing the new" becomes a "metaphysical need" for the early modern era. ${ }^{81}$

\section{HISTORY OF SCIENCE AS BLUMENBERG'S THEORETICAL ATTITUDE}

Blumenberg's historicization of technology emphasizes its connection with other forms of creative action, resisting the opposition of technology and art. His historicization of science, likewise, describes the sciences as continuing to contain an element of the "theoretical attitude" that unites rather than opposes them with philosophical inquiry and the humanities more widely. Blumenberg uses several slightly different terms for this "attitude" in German; more so than Einstellung, the word Haltung has a moral connotation. Displaying Haltung is associated with standing up to the unjust, with showing character under pressure. The importance of this term in historizing the sciences and technology in Blumenberg's work is, as I have sought to show in this article, not a coincidence. Blumenberg attached a rare moral importance to the pensiveness, Nachdenklichkeit, ${ }^{82}$ that for him

\footnotetext{
${ }^{79}$ Blumenberg, “Lebenswelt und Technisierung," 14.

80 "Das menschliche Schaffen sieht seinen Wirkungsraum sich durch das Gegebene benommen," Blumenberg, "Nachahmung," 62. Cf. Wertz, "On the possibility," 23.

81 "Metaphysisches Bedürfnis," Blumenberg, "Nachahmung," 57. See Wertz's introduction to "On the possibility" on the "metaphysical need," 8.

${ }^{82}$ Blumenberg, "Nachdenklichkeit," speech delivered before the Deutsche Akademie für Sprache und Dichtung in acceptance of the 1980 Sigmund Freud prize, https:/www.deut scheakademie.de/de/auszeichnungen/sigmund-freud-preis/hans-blumenberg/dankrede.
} 
characterized the human. While distinct from its outputs, it should continue to underpin the broad spectrum of inquiry from molecular biology to philosophy-a demand he felt all too keenly was challenged in the institutional environment he was working in.

His 1974 speech commemorating Ernst Cassirer was one of the few occasions when Blumenberg made explicit the urgency of his insistence on the importance of the theoretical attitude. Against attempts to render the past as relevant for the present, he argued that the historian's variant of the theoretical attitude serves the cultivation of respect toward those inhabiting the past, to save who and what has been from indifference as a moral "obligation not to give up on what is human." ${ }^{33} \mathrm{He}$ singled out the history of the sciences in teaching this lesson. A historical perspective on the sciences brings into view controversies, and some beliefs and methodological convictions that retrospectively turn out to be false-among Blumenberg's characteristically colorful picks are Augustine writing that "the stars were created for the consolation of people obliged to be active at night," and "Linnaeus's opinion that the song of the birds at the first light of morning was instituted as consolation for the insomnia of the old." ${ }^{44}$ Crucially for him, there is more than an epistemological or historiographical advantage at stake in paying attention to the "losers." He says, "We must distinguish between, on the one hand, the thought prohibition of teleological elements in modern theories and, on the other hand, historical respect for the equal rank of the aids man avails himself of in comprehending the world. History is precisely the theoretical attitude that allows us to do this. History of science is the specific form of history that makes it especially difficult for us, but which for that very reason can become a test of what is possible in our relation to history [Geschichtsverhältnis]." ${ }^{85}$ Recognizing mistaken beliefs as such without losing respect for their role in a belief system, both in heuristic and pragmatic terms, is the conceptual aim of the "relation to history" Blumenberg demands as the historian's variant of the theoretical

83 "Elementare Obligation, Menschliches nicht verloren zu geben," Blumenberg, "Ernst Cassirers gedenkend," in Wirklichkeiten, 163-72, at 170. On this argument, see Dieter Thomä, "Zeit und Neuzeit: Erkenntnis, Erinnerung, Leben: Spannungsverhältnisse," in Wetz and Timm, Kunst des Überlebens, 266-87, esp. 278-81.

84 "Augustin schrieb, die Sterne seien geschaffen worden zum Trost für die zu nächtlicher Tätigkeit genötigten Menschen, und Linné hielt dafür, der Gesang der Vögel beim ersten Morgenlicht sei zum Trost für die Schlaflosigkeit der Alten angesetzt," Die Genesis der kopernikanischen Welt, 202; Blumenberg, The Genesis of the Copernican World, 171.

85 "Wir müssen zwischen dem Denkverbot für teleologische Elemente in modernen Theorien und dem geschichtlichen Respekt vor der Gleichrangigkeit der menschlichen Selbsthilfen im Weltverständnis unterscheiden," Die Genesis der kopernikanischen Welt, 202; Blumenberg, The Genesis of the Copernican World, 171-72. 
attitude, and that he himself developed in his work with his Zettelkasten over a lifetime; its moral counterpart is to "pay respect to those who have become obscure," to appreciate "in their person their being part of humanity." ${ }^{86}$

University of Sydney.

86 "Den obskur Gewordenen Respekt zu erweisen"; "den Anteil an der Menschheit in ihrer Person gewürdigt und bewahrt zu sehen," Blumenberg, "Cassirers gedenkend," $170-71$. 